\title{
Who is Emmanuel Todd?
}

\author{
Julien Larregue ${ }^{1}$
}

Published online: 6 June 2017

(C) Springer Science+Business Media New York 2017

In this special issue devoted to contemporary French sociology, political scientist Anne Verjus sheds light on the intense controversy that followed the publication of Emmanuel Todd's Who is Charlie? in the aftermath of the Charlie Hebdo terrorist attacks in Paris (Verjus 2017; Verjus' defense of Todd is only applicable to Who is Charlie? and should not be extended to his recent communications during the French presidential election). From his own words, Todd's ambition was no less than to "[take] apart the infernal machinery that leads from a decaying or 'zombie' Catholicism to Islamophobia" (Todd 2015, Preface to the English Edition). But before answering the question Who is Charlie? maybe we should first ask, who is Emmanuel Todd?

Todd was born in Saint-Germain-en-Laye (a mid-sized town located in the Paris suburbs) in 1951. His social origins are important to notice, for Todd has inherited an important volume of cultural capital. His father, Olivier Todd, is a renowned leftist journalist who wrote several novels and biographies of prominent French authors (including Albert Camus and André Malraux). Todd's mother, Anne-Marie Nizan, was born from communist journalist and philosopher Paul-Yves Nizan. This cultural capital would play a determinant role in Emmanuel Todd's trajectory. Historian Emmanuel Le Roy Ladurie, a friend of Todd's parents who today holds the Chaire d'histoire de la civilisation moderne at the prestigious Collège de France, would become Todd's mentor and train him in the discipline of historical anthropology. Le Roy Ladurie's active participation to the interdisciplinary Ecole des Annales can explain some features of Todd's historical research, including the use of statistical and cartographic methods (an orientation that is clearly visible in Who is Charlie?). While Todd was completing his graduate (master-level) education in history at Université ParisSorbonne, Emmanuel Le Roy Ladurie introduced him to prominent British historian Peter Laslett. Todd spent three years in a PhD program at the University of Cambridge, where he studied familial systems with Laslett at Trinity College. Todd's dissertation, entitled Seven Peasant Communities in Pre-Industrial Europe (Todd 1976a), is a perfect illustration of his interest in familial and social structures.

Julien Larregue

julien.larregue@univ-amu.fr

1 Law School, LDPSC EA 4690, Aix-Marseille Université, Aix-en-Provence, France 
Interestingly, despite this prestigious academic trajectory, Todd did not end up occupying a distinguished position within a renowned history department. In fact, it is quite fair to say that Emmanuel Todd has occupied a heterodox position within French academia since the 1970s. Todd is not a university professor, nor a CNRS (National Center for Scientific Research) researcher, as would command the orthodox and classical career trajectory in French social sciences and humanities. Instead, Todd is a research engineer at the Institut National d'Etudes Démographiques (INED), a position that can be accessed without holding a doctoral degree. Although I do not know whether or not this unconventional career choice was deliberate, it has likely played a role in the - negative - reception of Todd's work in academic circles. Todd also regularly appears in mass media and non-scientific outlets, giving his opinion and thoughts about political and societal issues alike. For instance, he opposed the Maastricht Treaty in the 1990s (Favereau 1995) and the creation of a unique European currency (Todd 1996), and he publicly supported François Hollande's presidential candidacy against Nicolas Sarkozy in 2012 (Aeschimann and Algalarrondo 2012).

Emmanuel Todd's research interests broadly revolve around ideology and religion, familial structures, and modern states and societies. For instance, in The Explanation of Ideology: Family Structure and Social Systems, Todd argues that worldwide variations in politics and ideology are to be explained by differing familial structures (Todd 1989). His theorization of familial systems, which goes back to his $\mathrm{PhD}$ dissertation at Cambridge, is also outlined in L'origine des systèmes familiaux (Todd 2011). Another - yet related - stream of Todd's research focuses on modern states and societies. In 1976, he notoriously predicted the collapse of the Soviet Union in a book called La chute finale (Todd 1976b). In the same vein, the University of Columbia Press published After the Empire: The Breakdown of the American Order, a provocative piece in which Todd predicted, on the grounds of demographic and statistical data, that the United States would lose its status of superpower and be replaced by an Eurasian alliance (Todd 2006). Who is Charlie? is thus to be placed within Todd's broader interest in ideologies - be they political or religious - in the context of modern state systems.

\section{References}

Aeschimann, E., \& Algalarrondo, H. (2012). Emmanuel Todd: "Je parie sur l'hollandisme révolutionnaire !" L'Obs. http://tempsreel.nouvelobs.com/politique/election-presidentielle-2012/20120304.OBS2872 /emmanuel-todd-je-parie-sur-l-hollandisme-revolutionnaire.html. Accessed 27 Apr 2017.

Favereau, E. (1995). Club "Phares et Balises" et Fondation Saint-Simon: Ces dîners qui ont brisé la glace entre Chirac et des intellectuels de gauche. Libération.fr. http://www.liberation.fr/France-archive/1995/03/14 /club-phares-et-balises-et-fondation-saint-simon-ces-diners-qui-ont-brise-la-glace-entre-chirac-etde_127239. Accessed 27 Apr 2017.

Todd, E. (1976a). Seven peasant communities in pre-industrial Europe. In A comparative study of French, Italian and Swedish rural parishes (18th and early 19th century) (doctoral dissertation). Cambridge: University of Retrieved from https://www.repository.cam.ac.uk/handle/1810/244950.

Todd, E. (1976b). La chute finale: essai sur la décomposition de la sphère soviétique. Paris: Robert Laffont. Todd, E. (1989). The explanation of ideology: Family structure and social systems. Oxford: Blackwell.

Todd, E. (1996). L'invention de l'Europe. Paris: Seuil.

Todd, E. (2006). After the empire: The breakdown of the American order. New York: Columbia University Press. Todd, E. (2011). L'origine des systèmes familiaux. Paris: Gallimard.

Todd, E. (2015). Who is Charlie?: Xenophobia and the new middle class. Cambridge: Polity Press.

Verjus, A. (2017). A disputed truth. Defending Emmanuel Todd's Approach of Je suis Charlie. The American Sociologist, Forthcoming. 